\title{
Response of Campylobacter pyloridis to antibiotics, bismuth and an acid-reducing agent in vitro-an ultrastructural study
}

\author{
J. A. ARMSTRONG, S. H. WEE, C. S. GOODWIN and D. H. WILSON
}

Departments of Electronmicroscopy and Microbiology, Royal Perth Hospital, Box X2213, GPO, Perth, Western Australia, 6001

\begin{abstract}
Summary. Campylobacter pyloridis was cultured for maximal growth in liquid medium, and effects of exposure to various $\beta$-lactam and macrolide antibiotics, metronidazole, tripotassium dicitrato bismuthate (TDB) and cimetidine were monitored by transmission electronmicroscopy after periods of exposure up to $24 \mathrm{~h}$. With amoxycillin and benzylpenicillin $(0 \cdot 12-1 \mathrm{mg} / \mathrm{L})$ and cephalexin $(2 \mathrm{mg} / \mathrm{L})$ the normal bacilliform morphology was replaced by bulging and dumb-bell-like profiles showing cell-wall blebbing and vesiculation, and eventually by swollen forms with incomplete cell walls undergoing lysis. These changes developed progressively between $2 \mathrm{~h}$ and $24 \mathrm{~h}$ and were accelerated at the higher antibiotic concentrations. Erythromycin and clindamycin caused central clearing, ribosomal coagulation and impaired cross-wall formation. There were no gross structural changes in the presence of metronidazole (4 mg/L), TDB (1000 and $2400 \mathrm{mg} / \mathrm{L})$ or cimetidine (1000 and $2000 \mathrm{mg} / \mathrm{L})$; but with TDB focal accumulation of particulate bismuth complex was detected under the cell wall, affecting nearly all organisms by $24 \mathrm{~h}$. In parallel viability tests, metronidazole and TDB both showed bactericidal activity, but cimetidine did not. These findings support the clinical experience that favours combination therapy with bismuth plus an appropriate systemic antibiotic as the regimen of choice for effective clearance of the organisms in C. pyloridis-associated gastritis.
\end{abstract}

\section{Introduction}

Colonisation of the gastric epithelium by Campylobacter pyloridis, a distinctive spiral or curved bacilliform bacterium with multiple unipolar sheathed flagella, is strongly associated with antral gastritis and duodenal ulceration; and appropriate antibacterial treatment has been shown to remove these organisms and to alleviate symptoms referable to the gastric and duodenal lesions (Marshall et al. $1985 a$ and $b$; Goodwin et al., 1986b). Successful treatment may require a combination of an oral bismuth preparation, such as tripotassium dicitrato bismuthate (De-Nol ${ }^{\circledR}$, Gist-Brocades) which is presumed to act topically in the stomach, together with an appropriate systemic antibiotic. Apparent morphological effects of tripotassium dicitrato bismuthate (TDB) on C. pyloridis in vivo were detected ultrastructurally in endoscopic biopsy specimens of the stomach obtained from patients before treatment and between 30 and 90 min after ingestion of TDB (Marshall et al., 1985b, and in

Received 16 Dec. 1986; accepted 19 Feb. 1987. press). After these short intervals following a single dose of TDB, nearly all of the bacteria appeared to be severely damaged and to have mostly detached from the epithelial-cell surfaces. Dense deposits of bismuth were present around and within the damaged organisms, but the antibacterial mechanism remains obscure. Therefore, we wished to study the interaction in vitro between $C$. pyloridis, bismuth preparations and antibiotics, and to ex-s amine the resulting ultrastructural changes as a means of determining possible sites and modes of antibacterial activity. We have previously described some distinctive ultrastructural features of C. pyloridis in vivo, as seen on the surface of the human gastric antral mucosa (Goodwin et al., 1985, $1986 b$ ). Here we report the findings, from a study in which transmission electronmicroscopy was used, of the response of $C$. pyloridis in vitro to a range of antibiotics as well as to TDB and cimetidine, a drug that blocks histamine $\mathrm{H}_{2}$ receptors and is presently employed widely in treatment of peptic ulcer disease. Special growth conditions were adopted for these ultrastructural studies because the organism grows slowly in vitro, 
and such cultures often include a proportion of degenerate forms.

\section{Materials and methods}

\section{Bacterial cultures}

C. pyloridis NCTC 11637 consistently grows vigorously and was selected for this study. Stock cultures were kept in semi-solid medium containing Brain Heart Infusion Broth (Oxoid), agar $0.17 \%$, horse serum $10 \%$ and yeast extract $0.25 \%$, in a $\mathrm{CO}_{2}$ incubator at $37^{\circ} \mathrm{C}$ with $98 \%$ humidity. They were subcultured monthly into the same medium. The liquid medium employed was as above, but without agar. Because $C$. pyloridis requires a shallow depth of fluid in liquid medium to produce vigorous growth, a final volume of $3 \mathrm{ml}$ was used in $60-\mathrm{ml}(42-\mathrm{mm}$ diameter) flat-bottom specimen containers. Cultures were incubated in an atmosphere of $\mathrm{CO}_{2} 8 \%, \mathrm{O}_{2} 5 \%, \mathrm{H}_{2} 7 \%$, $\mathrm{N}_{2} 80 \%$ in an anaerobic jar which was placed on a reciprocating shaker at $37^{\circ} \mathrm{C}$.

Initially, control preparations of $C$. pyloridis were processed for electronmicroscopy after one subculture from semi-solid agar into the liquid medium. Such onetransfer cultures, however, always contained a proportion of atypical or spherical bacteria, including degenerate forms, which might be confused with an antibacterial effect. To obtain cultures comprising virtually $100 \%$ intact and presumed viable organisms, three transfers at daily intervals into liquid medium were required, with an inoculum of 0.1 or $0.2 \mathrm{ml}$ to produce a slightly turbid suspension. Cultures older than $48 \mathrm{~h}$ were not used because they too usually contained at least some fragmenting bacteria. In each experiment, control cultures incubated for the same length of time were processed alongside cultures exposed to the test substances. If the controls showed atypical forms the experiment was rejected.

An unsuccessful attempt was made to induce spiral, in preference to curved or bacillary, forms of $C$. pyloridis in the cultures by the addition of increasing concentrations of methylcellulose, as reported by Hazell and Lee (1985). In our hands such cultures did not contain appreciably more spiral forms, and because the higher concentrations of methylcellulose also inhibited bacterial growth the technique was not adopted.

\section{Antimicrobial agents}

Amoxycillin was provided by Beechams, Sydney; cephalexin by Glaxo Australia Pty. Ltd; erythromycin by Abbott Australia and clindamycin by Upjohn Pty. Ltd. Benzyl penicillin and metronidazole powder were available locally. TDB, in the form of De-Nol ${ }^{\mathbb{B}}$ powder, was supplied by Gist-Brocades (Holland), and cimetidine by Smith, Kline and French Laboratories.

\section{Addition of antibacterial test compounds}

The final concentrations of antibiotics employed in the study were chosen to be below or about equal to the blood concentrations achieved in vivo in man after standard oral doses; e.g., amoxycillin was tested at concentrations of $0 \cdot 12-1 \mathrm{mg} / \mathrm{L}$. The TDB powder dissolved readily in water; the final concentrations tested were 1000 and $2400 \mathrm{mg} / \mathrm{L}$, which are below or approximately the same as the concentrations expected in the stomach after swallowing one chewed tablet of De-Nol. Antibiotics and the other test compounds were added to liquid cultures that had been incubated for $5-18 \mathrm{~h} ; 0.1 \mathrm{ml}$ of the appropriate dilution of the test substance was added to the culture. To assess the onset and progression of ultrastructural changes, cultures were prepared for electronmicroscopy at various times from $1 \mathrm{~h}$ to $24 \mathrm{~h}$ after addition of the antibiotics. Cultures to which TDB was added were also examined after exposure for 20 and $40 \mathrm{~min}$. In supplementary tests with TDB, immune serum with a high titre of anti-C. pyloridis antibody was added with the bismuth compound in an attempt to simulate more closely conditions in the stomach of individuals with C. pyloridis-associated gastritis.

The minimum inhibitory concentration (MIC) for each of the several test substances was determined by the methods reported by Goodwin et al. (1986a).

\section{Bacterial viability tests}

The organisms were grown as for electronmicroscopy, with three transfers in fresh liquid media. On the last transfer they were subcultured into $7 \mathrm{ml}$ of medium. After $15 \mathrm{~h}$ this was divided into $3-\mathrm{ml} \mathrm{samples,} \mathrm{and} 0.1 \mathrm{ml}$ of sterile distilled water or the antibacterial test solution was added. At times from zero to $32 \mathrm{~h}, 0 \cdot 2-\mathrm{ml}$ samples from control and test cultures were taken and serial 1 in 10 dilutions made; $0.1 \mathrm{ml}$ of each, from neat to $10^{8}$ dilution, was plated on to Oxoid GC base (Code CM367) with added Iso-Vitalex (BBL, Microbiology Systems) $1 \%$, and chocolatised blood $5 \%$, in a campylobacter gas mixture. After 3 days visible colonies were counted and expressed as colony forming units (cfu)/ml.

\section{Electronmicroscopy}

Bacteria from control and treated cultures were fixed by adding to the $3 \mathrm{ml}$ of culture broth $5 \mathrm{ml}$ of glutaraldehyde $2.5 \%$ in $0.1 \mathrm{M}$ sodium cacodylate buffer, $p \mathrm{H} 7 \cdot 2$, and allowing the mixture to stand at room temperature for at least $2 \mathrm{~h}$. The organisms were deposited by centrifugation for $5 \mathrm{~min}$ at $1000 \mathrm{rpm}$ in a $10-\mathrm{ml}$ tube, washed once in cacodylate buffer and resuspended in $0.3 \mathrm{ml}$ of a sterile solution of bovine albumin $10 \%$ in water. They were transferred by plastic pipette into a $0.4-\mathrm{ml}$ Beckman 'Microfuge' tube and centrifuged again for $5 \mathrm{~min}$ at $1500 \mathrm{rpm}$. The supernate was removed and replaced by $0.3 \mathrm{ml}$ of glutaraldehyde $(2.5 \%)$ fixative solution, which was added carefully so as not to disturb the bacterial pellet. After standing overnight the gelled pellet was cut into $2-\mathrm{mm}$ cubes. Specimens were post-fixed for $1 \mathrm{~h}$ in osmium tetroxide $1 \% \mathrm{w} / \mathrm{v}$ solution, dehydrated and embedded in Araldite epoxy resin. Thin sections were cut and mounted on uncoated grids. Sections were stained 
either directly by the standard aqueous uranyl acetatelead citrate method (Reynolds, 1963), or after preliminary treatment for $30 \mathrm{~min}$ with uranyl acetate $15 \% \mathrm{w} / \mathrm{v}$ in nitric acid $5 \%$, followed by rinsing in distilled water for $1 \mathrm{~min}$. This modification appreciably enhanced the bacterial image contrast. Other sections were deliberately examined without staining, to facilitate detection of electron-dense particulate deposits within the organisms. Micrographs were obtained with a Philips EM410 (HM) transmission electronmicroscope at 60 or $80 \mathrm{kV}$.

\section{Results}

\section{Minimum inhibitory concentrations (MICs)}

Growth of $C$. pyloridis in liquid medium was inhibited by the respective test preparations at the following concentrations: amoxycillin and benzyl penicillin $0.015 \mathrm{mg} / \mathrm{L}$, cephalexin $0.6 \mathrm{mg} / \mathrm{L}$, erythromycin $0.06 \mathrm{mg} / \mathrm{L}$, clindamycin $0.6 \mathrm{mg} / \mathrm{L}$, metronidazole $0.8 \mathrm{mg} / \mathrm{L}$, TDB $8 \mathrm{mg} / \mathrm{L}$ and cimetidine $200 \mathrm{mg} / \mathrm{L}$.

\section{Ultrastructure studies}

Control cultures. Morphology of organisms in the untreated control cultures was comparable in most respects to that observed in biopsy specimens of heavily colonised gastric mucosa (Marshall and Warren, 1984; Marshall et al., 1984; Goodwin et al., 1985; Tricottet et al., 1986). The sectioned bacteria (fig. 1) appeared as slightly curved or straight bacillary profiles approximately $0.5 \mu \mathrm{m}$ wide and up to $3.5 \mu \mathrm{m}$ long, with bluntly rounded ends; they lacked the pit-like depression characteristic of other Campylobacter spp. Unipolar sheathed flagella with terminal bulbs were usually evident. The unit membrane of the cell wall appeared smooth and adhered closely to the underlying cytoplasmic membrane; this, in turn, enclosed a relatively homogeneous bacterial cytoplasm comprising dispersed ribosome particles with interspersed irregular lucent areas containing the nuclear fibrillar material. In two respects the morphology of cells grown in vitro differed somewhat from that occurring in vivo on the gastric mucosa; truly spiral forms were encountered only occasionally in the cultured cells and there was appreciable variation in the flagellar development. Few organisms had more than one or two flagella, and sometimes they were entirely lacking.

Within limits imposed by this variation it was possible to follow a procedure of assessing structural changes occurring in the presence of the putative antibacterials only when sections of parallel con-

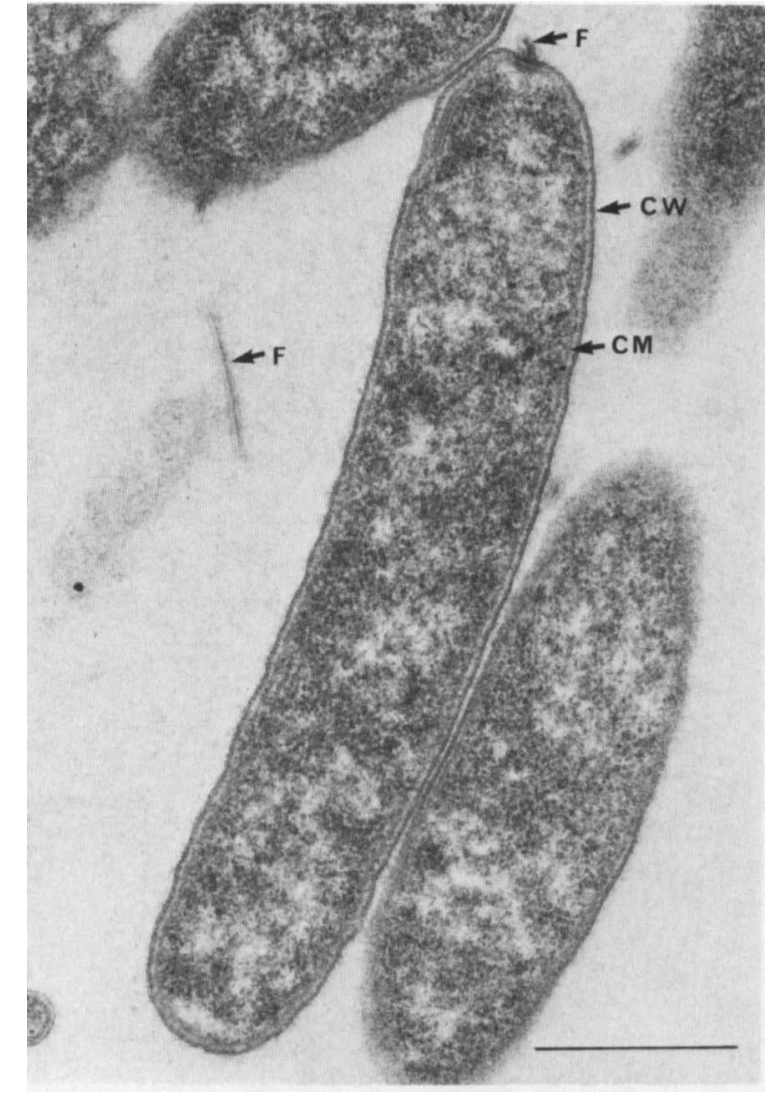

Fig. 1. Typical thin-section appearance of a curved bacilliform C. pyloridis cell from a control $8-\mathrm{h}$ culture. Notable details include a close fitting cell-wall membrane $(\mathrm{CW})$, cytoplasmic membrane (CM) and transected sheathed flagella (F). $\mathrm{Bar}=500 \mathrm{~nm}$.

trols revealed uniformly intact, and presumably viable, bacterial profiles.

Effects of amoxycillin, benzylpenicillin and cephalexin. Cultures were exposed to amoxycillin at concentrations of $0 \cdot 12,0 \cdot 25,0.5$ and $1 \mathrm{mg} / \mathrm{L}$; and were sampled for electronmicroscopy after exposure to antibiotic for $30 \mathrm{~min}$ and 1, 2, 4, 8 and $24 \mathrm{~h}$. No gross or ultrastructural changes were detected up to $2 \mathrm{~h}$, irrespective of the antibiotic concentration (fig. 2). From $2 \mathrm{~h}$ onwards, sections revealed progressively increasing proportions of atypical bacterial profiles (figs. 3-6), involving three distinctive phenomena: (1) gradual replacement of regular bacillary profiles by elongated forms with irregular bulging protrusions and by rounded or dumb-bellshaped forms measuring up to $1 \mu \mathrm{m}$ in diameter; (2) development of focal cell-wall blebs, and of free membranous vesicles or tubular structures $(100$ $200 \mathrm{~nm}$ in diameter) arising as apparent extrusions of the cell-wall membrane (fig. 5); (3) further 


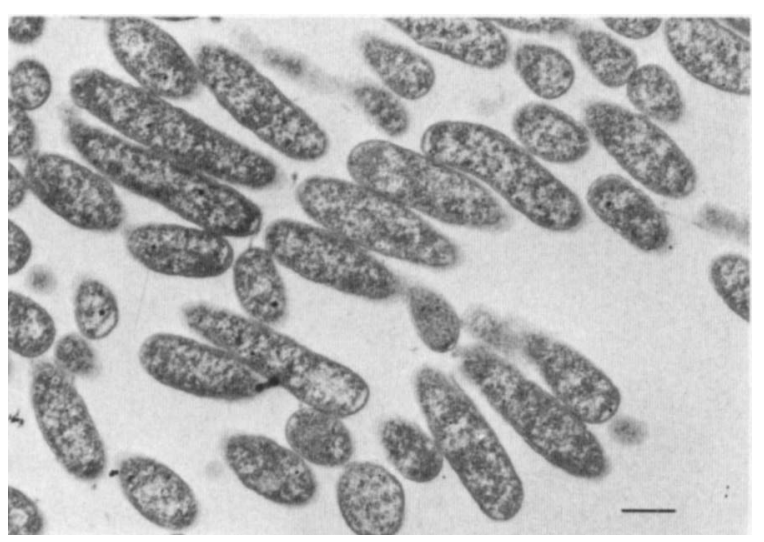

Fig. 2. C. pyloridis exposed to amoxycillin $0.5 \mathrm{mg} / \mathrm{L}$ for $1 \mathrm{~h}$. No obvious morphological abnormalities are apparent. $\mathrm{Bar}=500 \mathrm{~nm}$.

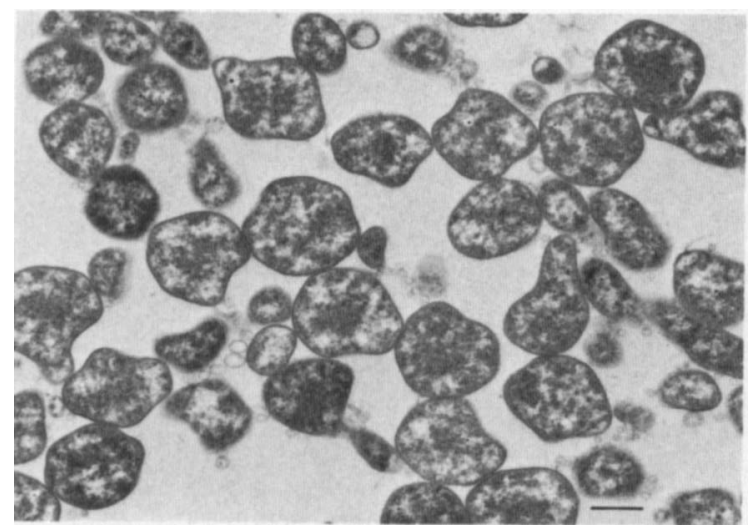

Fig. 3. Thin-section profiles of $C$. pyloridis exposed to amoxycillin $1 \mathrm{mg} / \mathrm{L}$ for $2 \mathrm{~h}$. Most of the organisms are rounded, swollen, and show occasional irregular bulges. $B a r=500 \mathrm{~nm}$.

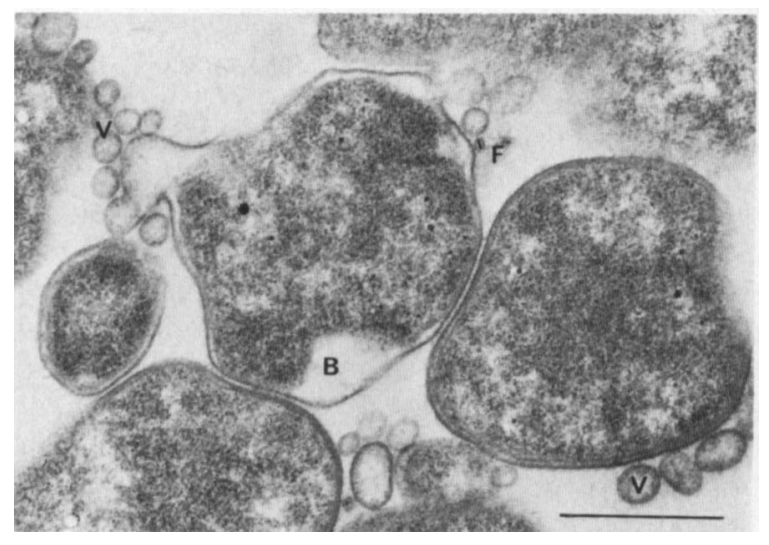

Fig. 4. C. pyloridis exposed to amoxycillin $0.25 \mathrm{mg} / \mathrm{L}$ for $4 \mathrm{~h}$, showing rounded cells with blebs (B) under the cell wall, and free membranous vesicles (V). Occasional flagella (F) are still present. $\mathrm{Bar}=500 \mathrm{~nm}$.

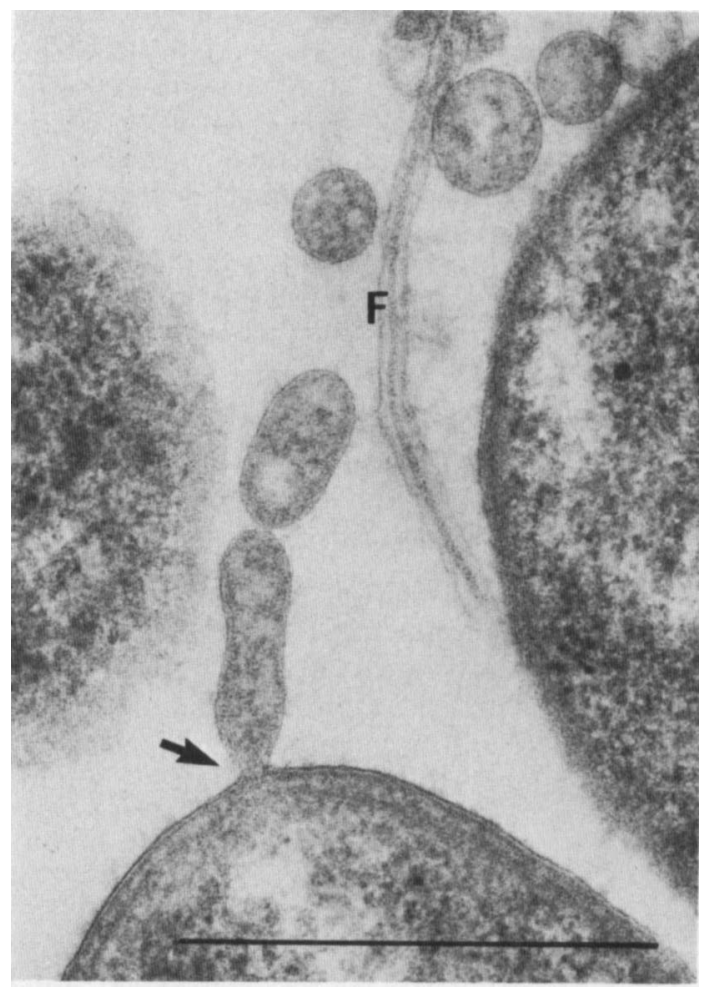

Fig. 5. C. pyloridis treated with amoxycillin $(0.5 \mathrm{mg} / \mathrm{L})$ for $4 \mathrm{~h}$. The vesicular structures appear to arise by shedding or extrusion from the cell-wall membrane (arrow). A longitudinally sectioned flagellum is also seen (F). Bar $=500 \mathrm{~nm}$.

enlargement, disruption and lysis of the spherical forms ( $1 \mu \mathrm{m}$ or more in diameter) associated with partial or complete disappearance of the external cell-wall membrane.

Bulging and rounding-up of still-intact organisms seemed to be early events, affecting $20-50 \%$ of organisms after $2 \mathrm{~h}$ depending on the concentration of amoxycillin; whereas cell-wall blebbing and free extruded vesicles were manifest in at least $90 \%$ after exposure for $4 \mathrm{~h}$ to even the lowest concentration tested. The most swollen, spheroplast-like forms with degenerative features (fig. 6) were prominent in cultures exposed for the longest time and to the highest concentrations tested, when no organisms of normal appearance remained.

Cultures exposed to benzylpenicillin, or to cephalexin, exhibited changes closely comparable to those described for amoxycillin. With benzylpenicillin $(1 \mathrm{mg} / \mathrm{L})$, round forms and cell-wall blebs were evident in some organisms after $2 \mathrm{~h}$. During the next $6 \mathrm{~h}$, most cells became similarly affected, with extruded vesicles, and the commencement of cell lysis. After $24 \mathrm{~h}$ almost all the organisms were 


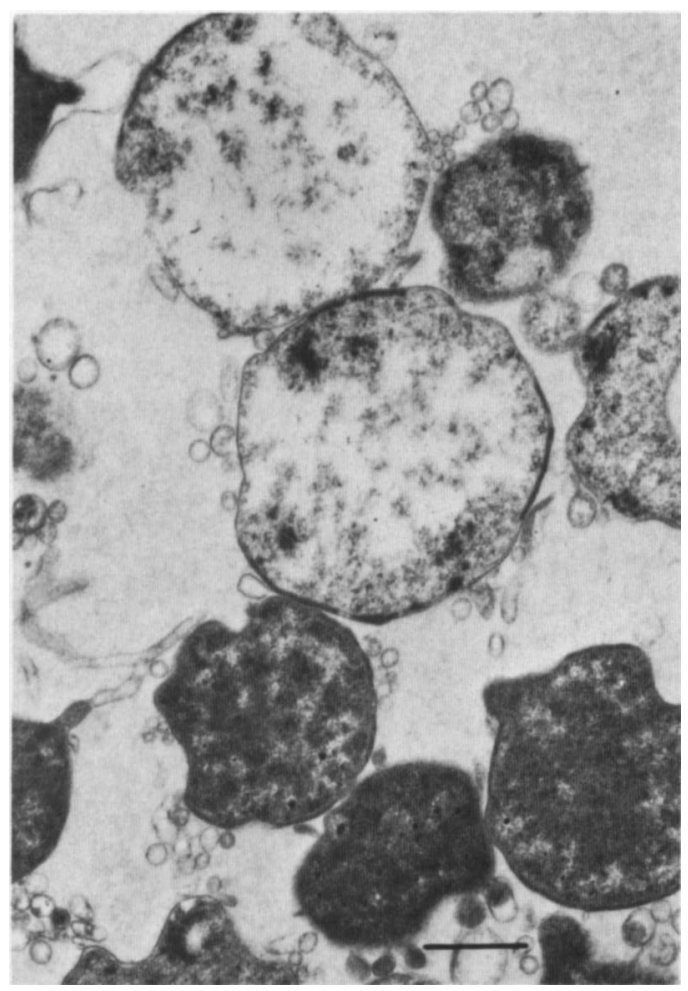

Fig. 6. Thin section of $C$. pyloridis culture treated with amoxycillin $0.5 \mathrm{mg} / \mathrm{L}$ for $24 \mathrm{~h}$. At this stage residual organisms, $1 \mu \mathrm{m}$ or more in diameter, show incipient lysis and some are bounded only by cytoplasmic membrane. Others show continued vesiculation and extrusion of cell wall membrane. $\mathrm{Bar}=500 \mathrm{~nm}$.

severely distorted and fragmentary. Cephalexin was tested at $2 \mathrm{mg} / \mathrm{L}$ and cultures examined after $1,3,8$ and $24 \mathrm{~h}$. No morphological changes were detected after $1 \mathrm{~h}$; but at $3 \mathrm{~h}$ about $10 \%$ of the organisms became rounded and bulging, with focal cell-wall blebbing, and by $8 \mathrm{~h}$ most were degenerating (fig. 7). This indicated a possibly more rapidly destructive outcome than that obtained with amoxycillin. Extrusion and shedding of free cell-wallderived vesicles and tubules were comparatively minor components of the cephalexin-induced sequence of changes.

Effects of erythromycin and clindamycin. Structural chañgês in $C$. pyloridis exposed to these macrolide compounds were less striking than those caused by the $\beta$-lactamantibiotics. Witherythromycin $1 \mathrm{mg} / \mathrm{L}$, no morphological change was perceptible at $3 \mathrm{~h}$, but after $8 \mathrm{~h}$ clear central areas were evident in some organisms, possibly due to dispersal of nuclear fibrillar elements. This response was seen in most cells by $24 \mathrm{~h}$. Similar but more obvious clear zones, accompanied often by ribosomal clumping or coagulation, were produced after 8 and $24 \mathrm{~h}$ in the presence of erythromycin $2 \mathrm{mg} / \mathrm{L}$ (fig. 8). The bacillary form of the bacteria was for the most part preserved, but aberrant profiles showing irregular constrictions or incomplete cross-wall development suggested additional impairment of bacterial division. Similar results were obtained in specimens exposed to clindamycin $8 \mathrm{mg} / \mathrm{L}$.

Effects of TDB, metronidazole and cimetidine. TDB was added at concentrations of 1000 and $2400 \mathrm{mg} / \mathrm{L}$, and samples for electronmicroscopy were taken after exposure for 20 and $40 \mathrm{~min}$, and 1 , 4,8 and $24 \mathrm{~h}$. In the routinely stained thin sections, no significant differences in the microbial ultrastructure were seen between treated and control cultures over the full period of observation; nor were large dense bismuth-like deposits seen on or

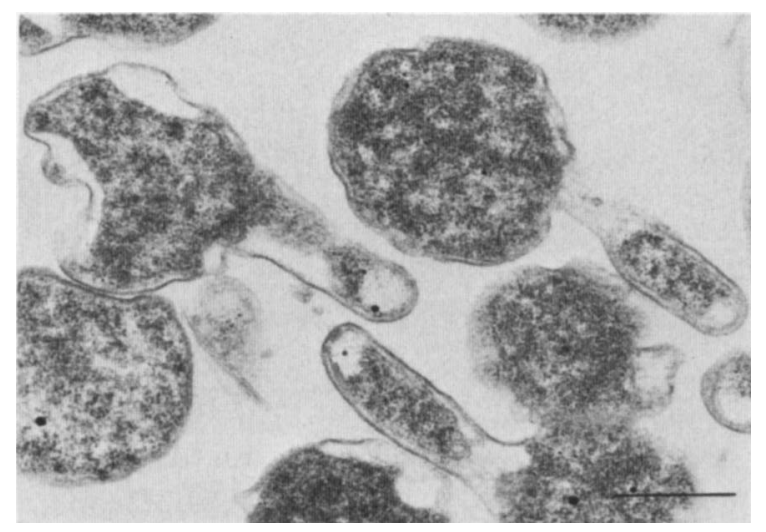

Fig. 7. C. pyloridis culture exposed to cephalexin $2 \mathrm{mg} / \mathrm{L}$ for $8 \mathrm{~h}$. The bacteria show rounding and finger-like bulges, with blebbing under cell walls. Cell wall vesiculation is minimal in comparison with that due to amoxycillin. Bar $=500 \mathrm{~nm}$.

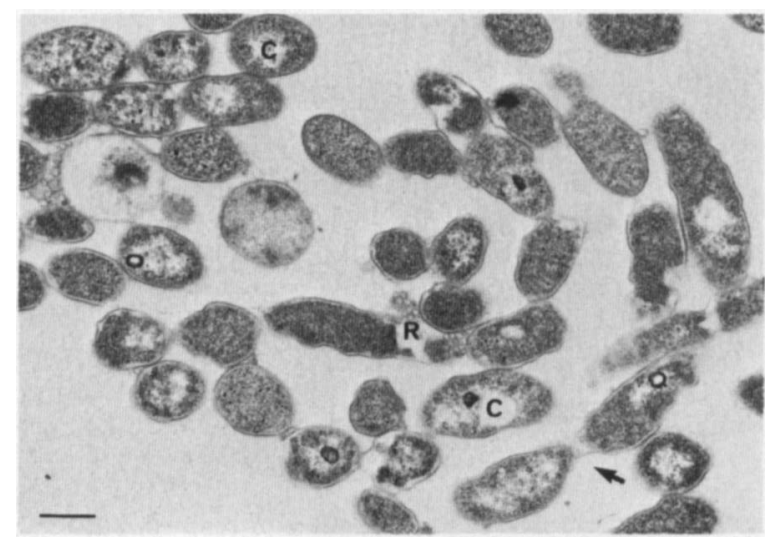

Fig. 8. Response of cultured C. pyloridis to erythromycin $2 \mathrm{mg} / \mathrm{L}$ for $24 \mathrm{~h}$. The bacillary profiles have irregular constrictions (arrow) and their contents are modified by focal clearing $(C)$ and retraction $(R)$. Bar $=500 \mathrm{~nm}$. 
adjacent to the organisms, like those we had seen previously around $C$. pyloridis in gastritis endoscopic biopsy specimens following a single therapeutic dose of De-Nol (Marshall et al., 1985b, and in press). However, inspection of corresponding unstained sections of the TDB-treated organisms revealed a distinctive pattern of electron-dense particulate deposits, the presence of which was partly obscured by the standard lead citrate and uranyl acetate contrast stains. The appearance resembled closely that of particulate deposits (designated "bismuth complex") in a recent ultrastructural study on the localisation of ingested TBD in the gastro-intestinal tract (Coghill et al., 1983). In sections of the affected $C$. pyloridis organisms it consisted of well defined rows or plaque-like accumulations of opaque particles measuring about $6 \mathrm{~nm}$ in diameter, and was limited in distribution to the periphery of the otherwise normal-looking bacterial cells (fig. 9). Its localisation was either in the space separating the cell wall and cytoplasmic membranes or, more often, directly adherent to the cytoplasmic membrane itself. No breaks or other defects of the external cell wall were observed to indicate where, or by what means, the particulate bismuth had penetrated the organisms. In cultures exposed to TDB for $4 \mathrm{~h}$, only occasional bacteria contained visible bismuth complex; after $8 \mathrm{~h}$, more than half were affected and virtually all after $24 \mathrm{~h}$. The appearances were the same with both concentrations of TDB tested. No similar opaque deposits

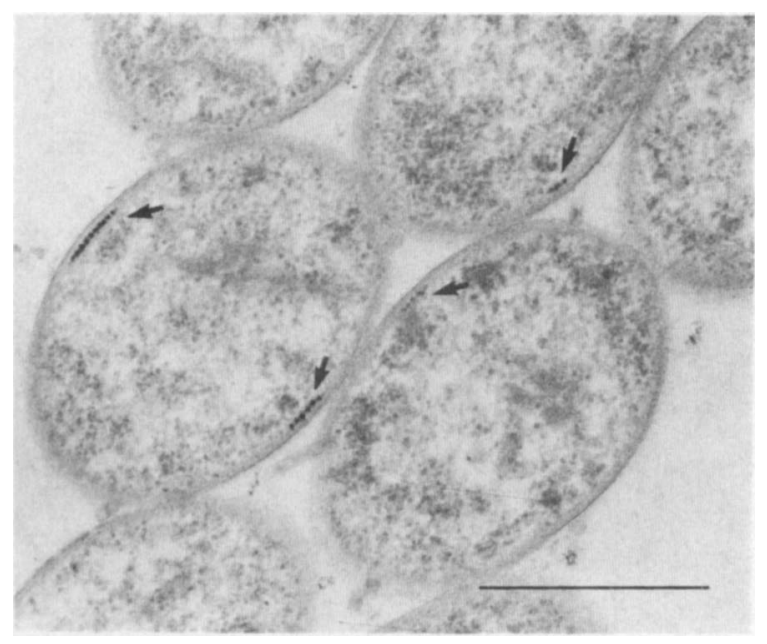

Fig. 9. Sectioned $C$. pyloridis organisms cultured for $8 \mathrm{~h}$ in the presence of TDB (De-Nol) at a concentration of $1000 \mathrm{mg} / \mathrm{L}$. Discrete plaque-like deposits of particulate "bismuth complex" are present under the cell walls of otherwise intact bacilli. The deposits appear closely adherent to the cytoplasmic membrane. $\mathrm{Bar}=500 \mathrm{~nm}$. were demonstrable in unstained sections of the parallel controls, or after exposure to any of the other antibacterials under test. Addition to TDBtreated cultures of human immune serum, containing antibodies to $C$. pyloridis, produced no further ultrastructural changes and neither facilitated nor impaired the penetration of bismuth complex through the cell walls. No significant alterations in overall bacterial morphology or ultrastructure, as revealed in thin sections, were produced by exposure for periods of 1-24 h to metronidazole $4 \mathrm{mg} / \mathrm{L}$ or cimetidine at 1000 or $2000 \mathrm{mg} / \mathrm{L}$.

\section{Bacterial viability tests}

In view of our inability to demonstrate bacteriolysis, or other major structural alterations in bacterial form, by exposure in vitro to TDB, metronidazole or cimetidine, it was of interest to determine whether the growth inhibiting characteristics (MIC) of these substances reflected significant bactericidal capabilities. The respective viability curves are shown in fig. 10. At concentrations equivalent to those used for the ultrastructural studies, TDB and metronidazole showed clear bactericidal effects; in comparison with parallel controls, $10^{3}$-fold differences in $\mathrm{cfu} / \mathrm{ml}$ were achieved by both substances after $24 \mathrm{~h}$. Supplementary tests performed with three different isolates of C. pyloridis produced almost identical killing curves. With cimetidine, in contrast, no evidence for bactericidal activity was obtained.

\section{Discussion}

We have found $C$.pyloridis to be very susceptible to $\beta$-lactam antibiotics. This substantiates the reported clinical efficacy of amoxycillin, when used either alone (Langenberg et al., 1985) or in combination with oral bismuth for clearance of $C$. pyloridis from the stomach of patients who relapsed after prior treatment with bismuth alone (Goodwin et al., 1986b). In vivo, the organisms occur predominantly on the luminal surface of the gastric antral mucosa; but small numbers are often sequestered in the gastric pits where they may escape exposure to oral bismuth preparations, leading to re-colonisation on cessation of such medication. These residual organisms may be accessible to a systemic antibiotic.

The morphological effects of penicillin on bacteria were first reported by Gardner (1940) who noted that large irregular forms occurred amongst grampositive bacteria in the presence of sub-inhibitory concentrations of the antibiotic; whereas gram- 

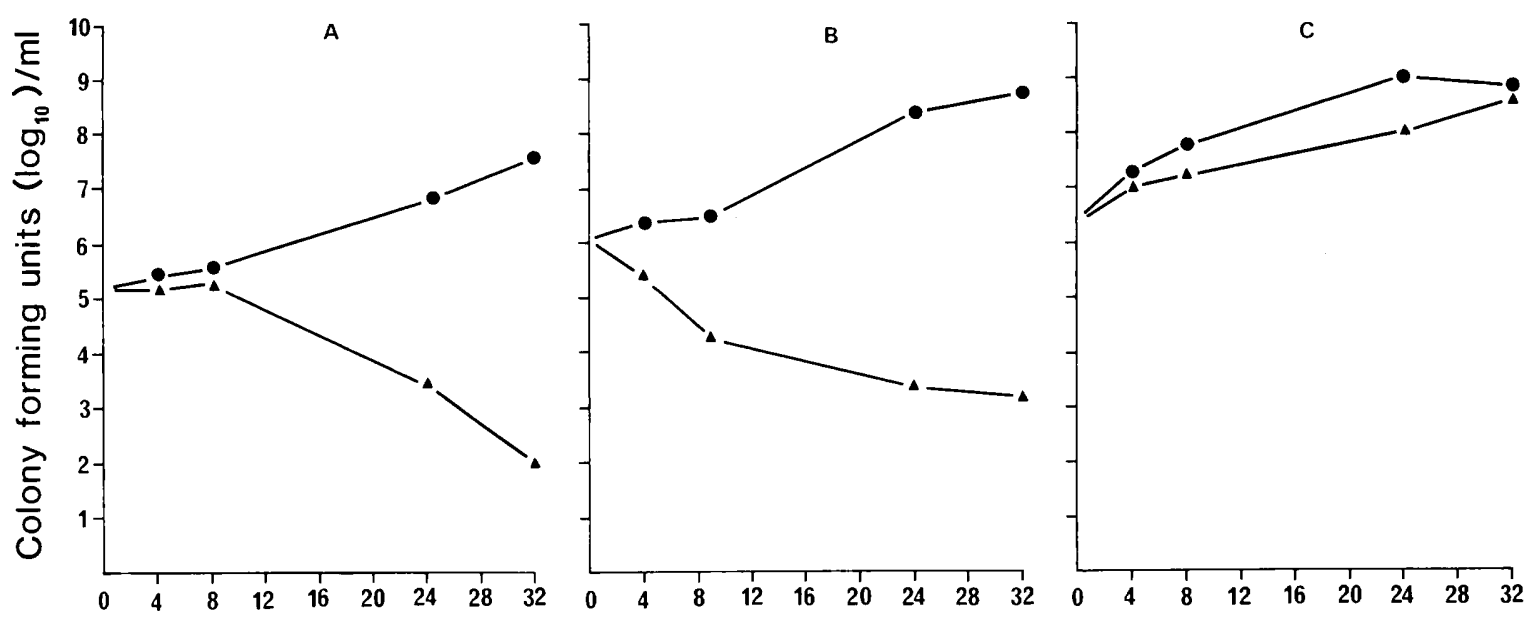

Time (h)

Fig. 10. Viable counts of cultured C. pyloridis NCTC 11637 exposed to (A) TDB (De-Nol) $1000 \mathrm{mg} / \mathrm{L}$, (B) metronidazole $4 \mathrm{mg} / \mathrm{L}$, or (C) cimetidine $2000 \mathrm{mg} / \mathrm{L} . \Delta \longrightarrow \Delta$ Test systems; $\longrightarrow$ controls.

negative rods formed long filaments. Similar illustrations appear in the classical work of Florey et al. (1949). Rolinson et al. (1977) reviewed the literature on the effects of the penicillins demonstrable by light microscopy, but until recently surprisingly little use has been made of transmission electronmicroscopy in this connection. Nishino and Nakezawa (1972) examined thin sections of filamentous forms of $E$. coli produced by cephalexin, revealing impaired microbial septa formation. More recently Elliott and Greenwood (1983, 1984) described ultrastructural changes in Pseudomonas aeruginosa exposed to a range of $\beta$-lactam antibiotics. The pattern of response was similar to that found in the present study, but in C.pyloridis vesicular extrusions of cell-wall membranes appeared to be a more prominent feature and filamentation was less marked.

The ultrastructural changes we found with erythromycin and clindamycin, though morphologically less striking than those attributable to amoxycillin, affected a majority of organisms in the test cultures by $24 \mathrm{~h}$. These antibiotics too may find a place in the control of $C$. pyloridis infection. McNulty et al. (1985) and Czinn et al. (1986) have identified several macrolide antibiotics that are active in vitro against this organism.

In view of the reported efficacy of bismuth compounds in treatment of $C$. pyloridis-associated gastritis (Goodwin et al., 1986b; Marshall et al., in press), it was somewhat surprising to find that, over a $24 \mathrm{~h}$ period, cultured organisms exposed to TDB exhibited no overt structural or degenerative changes. However, the focal deposits of particulate bismuth complex seen under the cell wall in most organisms after exposure for $8 \mathrm{~h}$ suggest the existence of a drug-related mechanism for breaching the cell wall to allow penetration of TDB. Viability tests clearly demonstrated bactericidal activity, but the killing effect became manifest only after exposure for more than $8 \mathrm{~h}$. In contrast, our previous sequential endoscopic biopsy studies of patients with gastritis (Marshall et al., 1985b, and in press) revealed very rapid bacterial degradation and detachment from the epithelial surface membranes. These effects were maximal in biopsy specimens taken less than $2 \mathrm{~h}$ after initial dosage, and only microbial debris remained when biopsies were taken at $24 \mathrm{~h}$. Conditions in vitro and in the human stomach are very different, and the antibacterial action may be enhanced or modified by factors peculiar to the gastric environment. The underlying mechanisms require further study. However, a concept we favour envisages inhibition by bismuth of the bacterial facility for epithelial adherence beneath the gastric mucus (Goodwin $e t$ $a l ., 1986 b)$. Once detached, the inactivated organisms would drift through the mucus layer, approach the hostile environment of the gastric lumen and be swept rapidly away.

Of the remaining compounds tested, both metronidazole and cimetidine produced no obvious morphological changes in cultured $C$. pyloridis. However, metronidazole exhibited bactericidal activity whereas cimetidine showed none. This suggests that even prolonged administration of 
such acid reducing drugs for peptic ulcer disease is unlikely to influence significantly any co-existing $C$. pyloridis infection. As indicated recently in reference to a possible role for persistent $C$. pyloridis gastritis as a predisposing factor for peptic ulceration (Axon, 1986) failure to eliminate the organism could relate to the high relapse rates reported after completion of conventional anti-acid treatments for duodenal ulceration (Bardhan et al., 1982). At

\section{REFERENCES}

Axon A T R 1986 Campylobacter pyloridis: what role in gastritis and peptic ulcer? British Medical Journal 293: 772-773.

Bardhan K D, Cole D S, Hawkins B W, Franks C R 1982 Does treatment with cimetidine extended beyond initial healing of duodenal ulcer reduce the subsequent relapse rate? British Medical Journal 284: 621-623.

Coghill S B, Hopwood D, McPherson S, Hislop S 1983 The ultrastructural localisation of De-Nol (colloidal tripotassium dicitrato-bismuthate-TDB) in the upper gastrointestinal tract of man and rodents following oral and instrumental administration. Journal of Pathology 139: 105114.

Czinn S, Carr H, Aronoff S 1986 Susceptibility of Campylobacter pyloridis to three macrolide antibiotics (erythromycin, roxithromycin [RU 28965], and CP 62,993) and rifampin. Antimicrobial Agents and Chemotherapy 30: 328-329.

Elliott T S J, Greenwood D 1983 The response of Pseudomonas aeruginosa to azlocillin, ticarcillin and cefsulodin. Journal of Medical Microbiology 16: 351-362.

Elliott T S J, Greenwood D 1984 The morphological response of Pseudomonas aeruginosa to azthreonam, cefoperazone, ceftazidime and $\mathbf{N}$-formimidoyl thienamycin. Journal of Medical Microbiology 17: 159-169.

Florey H W et al. 1949 Antibiotics, vol. II. Oxford University Press, London, pp 1144-1156.

Gardner A D 1940 Morphological effects of penicillin on bacteria. Nature 146: 837-838.

Goodwin C S, McCulloch R K, Armstrong J A, Wee S H 1985 Unusual cellular fatty acids and distinctive ultrastructure in a new spiral bacterium (Campylobacter pyloridis) from the human gastric mucosa. Journal of Medical Microbiology 19: $257-267$.

Goodwin C S, Blake P, Blincow E $1986 a$ The minimum inhibitory and bactericidal concentrations of antibiotics and anti-ulcer agents against Campylobacter pyloridis. Journal of Antimicrobial Chemotherapy 17: 309-314.

Goodwin C S, Armstrong J A, Marshall B J 1986 b Campylobacter pyloridis, gastritis, and peptic ulceration. Journal of Clinical Pathology 39: 353-365.

Hazell S L, Lee A 1985 The adaptation of motile strains of Campylobacter pyloridis to gastric mucus and their association with gastric epithelial intercellular spaces. In: Pearson A D et al. (eds) Campylobacter III : Proceedings of the third the present time the best prospect for eradication of $C$. pyloridis in vivo would seem to rest with combination regimens of oral bismuth plus a systemic antibiotic such as amoxycillin or metronidazole.

The financial support of Royal Perth Hospital Research Foundation for this investigation is gratefully acknowledged. We thank Dr R. Wilson for advice and discussions, and Carmel Neagle for her secretarial assistance.

international workshop on campylobacter infections. Public Health Laboratory Service, London, pp 189-191.

Langenberg M Let al. 1985 The pathogenic role of Campylobacter pyloridis studied by attempts to eliminate these organisms. In: Pearson A D et al. (eds) Campylobacter III : Proceedings of the third international workshop on campylobacter infections. Public Health Laboratory Service, London, pp $162-163$.

Marshall B J, Warren J R 1984 Unidentified curved bacilli in the stomach of patients with gastritis and peptic ulceration. Lancet 1: 1311-1314.

Marshall B J et al. 1984 Original isolation of Campylobacter pyloridis from human gastric mucosa. Microbios Letters 25 : 83-88.

Marshall B J, McGechie D B, Rogers P A, Glancy R J $1985 a$ Pyloric campylobacter infection and gastroduodenal disease. Medical Journal of Australia 142: 439-444.

Marshall B J, McGechie D B, Armstrong J A, Francis G $1985 b$ The antibacterial action of bismuth: early results of antibacterial regimens in the treatment of duodenal ulcer. In: Pearson A D et al. (eds) Campylobacter III : Proceedings of the third international workshop on campylobacter infections. Public Health Laboratory Service, London, pp $165-166$.

Marshall B J, Armstrong J A, Francis G J, Nokes N T, Wee $\mathrm{SH}$ The antibacterial action of bismuth in relation to Campylobacter pyloridis colonization and gastritis. Digestion (in press).

McNulty C A M, Dent J, Wise R 1985 Susceptibility of clinical isolates of Campylobacter pyloridis to eleven antimicrobial agents. Antimicrobial Agents and Chemotherapy 28: 837838.

Nishino T, Nakazawa S 1972 Morphological changes in Staphylococcus aureus and Escherichia coli exposed to cephalexin. Japan Journal of Microbiology 16: 83-94.

Reynolds E S 1963 The use of lead citrate at high $p \mathrm{H}$ as an electron-opaque stain in electron microscopy. Journal of Cell Biology 17: 208-213.

Rolinson G N, Macdonald A C, Wilson D A 1977 Bactericidal action of beta-lactam antibiotics on Escherichia coli with particular reference to ampicillin and amoxycillin. Journal of Antimicrobial Chemotherapy 3: 541-543.

Tricottet Vet al. 1986 Campylobacter-like organisms and surface epithelium abnormalities in active, chronic gastritis in humans: an ultrastructural study. Ultrastructural Pathology 10: $113-122$. 